Progress in Drug Research

Fortschritte der Arzneimittelforschung

Progrès des recherches pharmaceutiques

Vol.26 


\section{Progress in Drug Research Fortschritte der Arzneimittelforschung Progrès des recherches pharmaceutiques Vol. 26}

Edited by $\cdot$ Herausgegeben von - Rédigé par

Ernst Jucker, Basel

Authors $\cdot$ Autoren $\cdot$ Auteurs

R.W. Ashworth, E.W.J. de Maar, S. Johne, Y.V. Natochin,

M. Nath Pal, S.K. Puri and G.P. Dutta, A. Scriabine,

D. G. Taylor and E. Hong, S. Sharma and E.S. Charles,

E.K. Weisburger, W.D. Winters 
All rights reserved. No part of this publication may be reproduced, stored in a retrieval system, or transmitted in any form or by any means, electronical, mechanical, photocopying, recording or otherwise, without the prior permission of the copyright owner.

(C) 1982 Birkhäuser Verlag Basel

Softcover reprint of the hardcover lst edition 1982

ISBN-13:978-3-0348-7113-6

e-ISBN-13:978-3-0348-7111-2

DOI: $10.1007 / 978-3-0348-7111-2$ 


\section{Foreword}

Volume 26 of 'Progress in Drug Research' contains 10 articles, a subject index for this volume, an alphabetic subject index for volumes 1-26, and an author and subject index for all the volumes which have so far been published. The contributions of volume 26 cover a wide field of drug research and therapy, and some are directed towards tropical deseases. As in previous volumes, the authors have also tried not only to summarise the current status of particular fields of drug research, but also to provide leads for future research activity. The articles in this volume will be of special value not only to those actively engaged in resolving the diverse problems in drug research, but also to those who wish to keep abrest of the latest developments influencing modern therapy.

In addition, it is believed that the 26 volumes of "Progress in Drug Research" now available represent a useful reference work of an encyclopaedic character.

The editor would like to take the occasion of the publication of this volume to express his thanks both to the authors and to the readers. The authors have willingly undertaken the great labor of writing significant topical contributions, and many readers have helped the editor with criticism and advise. With his thanks to the authors and the readers, the editor would like also to express his gratitude to the publisher, Birkhäuser Verlag, Basel, and particularly to Messrs. Th. Birkhäuser and C. Einsele and their associates for the excellent cooperation. 


\section{Vorwort}

Der 26. Band der «Fortschritte der Arzneimittelforschung» umfasst 10 Beiträge und enthält ausserdem einen Index des Bandes, ein Sachverzeichnis und einen Autoren- und Artikelindex der Bände 1-26. Die Artikel des vorliegenden Bandes befassen sich mit verschiedenen aktuellen Problemen der Arzneimittelforschung und der Therapie; einige weisen in Richtung der Tropenkrankheiten.

Die Autoren auch dieses Bandes haben versucht, nicht nur ihre Fachgebiete übersichtlich darzustellen, sondern darüber hinaus, auch in die Zukunft weisende Betrachtungen anzustellen. Auf diese Weise wird auch dieser Band dem aktiven Forscher von Nutzen sein, und demjenigen, der sich über die neuesten Entwicklungen auf dem laufenden halten will, mancherlei Interessantes bieten.

Ausserdem darf angenommen werden, dass die jetzt vorliegenden 26 Bände ein wertvolles Nachschlagewerk mit enzyklopädischem Charakter darstellen.

Der Herausgeber möchte den Autoren und den Lesern der «Fortschritte der Arzneimittelforschung» danken; den Autoren für die grosse bei der Abfassung der Artikel geleistete Arbeit, den Lesern für ihre Kritik und Anregungen. Dank sei auch dem Birkhäuser Verlag, und insbesondere den Herren Th. Birkhäuser und C. Einsele sowie ihren Mitarbeitern für die ausgezeichnete Zusammenarbeit ausgesprochen. 


\section{Contents $\cdot$ Inhalt $\cdot$ Sommaire}

Chemotherapy of hookworm infections $\ldots \ldots \ldots \ldots \ldots \ldots \ldots, \quad 9$

By Dr. Satyavan Sharma and Dr. Elizabeth S. Charles

Drug and its action according to Ayurveda

By Dr. Shri Madhabendra Nath Pal

Mechanism of drugs action on ion and water transport in renal

tubular cells

By Prof. Dr. Yu.V. Natochin

Metabolic activation of chemical carcinogens

By Dr. Elizabeth K. Weisburger

Antibiotics in the chemotherapy of malaria

By Dr. S.K. Puri and Dr. G.P. Dutta

Drugs affecting the renin-angiotensin system

By Dr. Robert W. Ashworth

A review of the continuum of drug-induced states of excitation and depression

By Prof. Dr. W.D. Winters

Search of pharmaceutically interesting quinazoline derivatives:

Efforts and results (1969-1980)

By Dr. S. Johne

Some reflections on the chemotherapy of tropical diseases:

past, present and future

By Dr. Edmund W.J. de Maar

Central control of arterial pressure by drugs

By Dr. A. Scriabine, Dr. D. G. Taylor and Dr. E. Hong

Index · Sachverzeichnis - Table des matières, Vol.26 . . . . . . . . . . 373

Subject Index · Sachverzeichnis · Table des matières, Vol. 1-26 . . . . 377

Author and Paper Index - Autoren- und Artikelindex - Index des auteurs et des articles, Vol. 1-26 